\title{
Effect of chemical treatment on physiological quality of seed and control of Meloidogyne javanica in watermelon plants
}

\author{
Hélen Claudine Saliba Rodrigues ${ }^{1 *}$, Carolina Terra Borges ${ }^{1}$, Renan Navroski ${ }^{1}$, Vanessa Nogueira \\ Soares ${ }^{1}$, Gizele Ingrid Gadotti ${ }^{2}$, Géri Eduardo Meneghello ${ }^{1}$
}

\author{
${ }^{1}$ UFPEL, Faculdade de Agronomia Eliseu Maciel, Cx 354, Campus Capão do Leão, RS, Plant Science \\ Department, Universidade Federal de Pelotas, RS, BR, Brazil \\ ${ }^{2}$ Engineering Center, Universidade Federal de Pelotas, RS, BR, Brazil
}

*Corresponding author: helensaliba@gmail.com

\begin{abstract}
This study aimed to evaluate the efficacy of different concentrations of abamectin, in combination with thiabendazole and thiamethoxam, on seed physiological quality and on the control of Meloidogyne javanica in watermelon plants. To this purpose watermelon seeds of the Crimson Sweet variety were employed in the study. The treatment of the seeds consisted of abamectin (nematicide) at concentrations of $0.075 \mathrm{~g}\left(\mathrm{ST}_{2}\right), 0.150 \mathrm{~g}\left(\mathrm{ST}_{3}\right), 0.300 \mathrm{~g}\left(\mathrm{ST}_{4}\right)$ and $0.600 \mathrm{~g}\left(\mathrm{ST}_{5}\right)$ ai (active ingredients) per $1000 \mathrm{seeds}$ in combination with thiabendazole and thiamethoxam at concentrations of $0.080 \mathrm{~g}, 0,019 \mathrm{~g}$ ai per 1000 seeds, respectively. Untreated seeds $\left(\mathrm{ST}_{1}\right)$ were also employed as a control. The volume of the mixed solution used to this purpose was $4.9 \mathrm{~mL} 1000 \mathrm{seed}^{-1}$. The untreated and treated seeds were divided in two parts; the first part was sowed on paper towels and placed in chambers maintained at a constant $25^{\circ} \mathrm{C}$ while the second part was planted in trays in a greenhouse so as to enable evaluation of shoot length, shoot fresh weight, root weight, galls number, egg number, and reproduction factor. The physiological quality of the seeds was evaluated by standard germination tests, cold tests, and emergence speed index. The results indicated that the watermelon seed quality was not affected by concentration of abamectin when used in combination with thiabendazole and thiamethoxam. Further investigations are warranted in order to verify nematicidal toxicity on seed quality at higher levels of treatment. Based on the results of our study, we propose that abamectin ( 0.75 to $600 \mathrm{~g} /$ ai per 1000 seeds) when applied in combination with thiabendazole and thiamethoxam, is an effective control agent for reducing the number of eggs and second-stage juveniles (J2) in 'Crimson Sweet' watermelon plants.
\end{abstract}

Keywords: Cucurbits; Seed treatment; Root-knot nematodes; Abamectin; Thiabendazole; Thiamethoxam.

Abbreviation: ST_Seed treatment; ai_Active ingredients; SGT_Standard germination test; CT_Cold test; ESI_Emergence speed index; SL_Shoot length; SFW_Shoot fresh weight; RW_Root weight; cm_centimeters; g_grams; GN_Galls number; EN_Eggs number; RF_Reproduction factor; J2_Second_stage juveniles; RKN_Root-knot nematodes; FP_Final population of nematode; IP_Initial population; S_Susceptible; R_Resistant.

\section{Introduction}

Root-knot nematodes (Meloidogyne spp.) are microscopic parasites found in a wide variety of habitats and agroecosystems. These parasites are known to infect cucurbit plant roots in order to feed and complete their life cycles (Dormam and Nelson, 2012). Meloidogyne incognita, M. javanica, and $M$. arenaria are nematode species that attack vegetable crops; these parasites have the potential to cause severe damage to cucurbit crops especially in sandy-textured soils (Khalil et al., 2013). As damage caused by nematode interferes with the uptake of water and nutrients, the top portion of the plant adopts an appearance that mimics lack of moisture or fertilizer deficiency. Nematodes are known to complete the main part of their life cycle within the roots of the host plant although they are also known to survive in soil as eggs or as second-stage juveniles (Dorman and Nelson, 2012). Nematode-damaged plants are also more vulnerable to infection by other pathogenic inhabitants of cultivated soils (Fischer et al., 2008). The symptoms and cause of root-knot disease in cucurbits suggest towards the adoption of integrated management practices in order to limit crop loss and damage. The root-knot nematodes are responsible for at least $90 \%$ of all damage caused in plants (CasragnomeSereno, 2002). In last fifteen years, nematodes have been responsible for inflicting an estimated $\$ 118 \mathrm{~b}$ worth of loss to world crops annually. In an attempt to reduce the burden of loss inflicted by root-knot nematodes, several studies have been directed towards assessing the effects of chemical treatments, either singularly or in combination with other products, for the control of pests and their associated diseases (Ludwing et al., 2011). The efficiency and efficacy of combining fungicides with insecticides for the purpose of chemical control have been reported in some studies. However, very little is known about the effects of combining the above with the nematicide abamectin. This implies and underlines an urgent need for this technique to be further researched and analyzed.

Abamectin is an alternative biorational tool that has been used in the capacity of an insecticide-acaricide-nematicide on vegetable, fruit, and field crops. Abamectin belongs to the avermectin group which in turn is composed of macro cyclic lactone metabolites produced during the natural fermentation process of the bacterium Streptomyces avermitilis. This 
bacterium is known to contain approximately $80 \%$ avermectin $\mathrm{B} 1_{\mathrm{a}}$ and $20 \%$ avermectin $\mathrm{B} 1_{\mathrm{b}}$ (Khalil et al., 2013). In an abamectin mixture containing thiamethoxam haliland, the thiabendazole fungicide is considered as an alternative that enhances the protection of seedlings at a crucial phase in addition to delivering other physiological benefits that help during plant development (Dan et al. 2012).

Thiamethoxam is an insecticide that is widely used for treating carrot seeds and other crops so as to enhance seedling vigor, improve seed germination, and increase absorption of nutrients by the plant (Almeida et al., 2009). Thiabendazole is a fungicide that is popularly used as a broad-spectrum anthelmintic for several animal species as well as for humans. It is also used as a powerful systemic fungicide in leaf sprays, post-harvest fruit treatments (Oliveira et al., 2002; Fischer et al., 2008) as well as seed treatments (Moraes et al., 2003; Nerbass et al., 2008).

The use of a single product or a combination of two or more allows farmers the freedom to choose among all available options for crop management alternatives. This practice promotes faster crop stand development at lower costs besides controlling the incidence of pests and diseases in plants. Although other authors have also tested the potential of abamectin for controlling knot-root nematodes on cucurbits, the combination of abamectin and thiabendazole as a form of seed treatment has not been reported thus far (Vitti et al., 2014).

In order to fill this lacuna in our knowledge, it is imperative to conduct research into the possibility of seed treatment using a combination of nematicides with other chemical products in a manner that is complementary to the standard usually employed by farmers for controlling pests and diseases. Hence, it is the objective of this study to evaluate the efficacy of different concentrations of abamectin in combination with thiabendazole and thiamethoxam and to analyze its impact on seed physiological quality as well as on the control of Meloidogyne javanica in watermelon plants.

\section{Results and Discussion}

Physiological quality of watermelon seed treated with abamectin, thiabendazole, and thiamethoxam

Results generated by the standard germination test were unable to differentiate between seed treated and untreated specimens (Table 1). These results indicate that the concentrations of abamectin used for seed treatment in this study did not adversely affect the SG test of watermelon. Our results parallel those reported by Dan et al. (2011) who also claimed that treatment of soybean seeds with different chemicals has no impact on quality. A study conducted by Gassen (2006) has reported that some products, when applied alone or in combination, in certain situations cause phytotoxic effects, which in turn may lead to a reduction in seed germination and seedling survival levels. Castro and Pereira (2008) reported that, as observed in case of soybean, seeds treated with products containing thiamethoxam tend to germinate faster and more evenly due to stimulation of enzymatic activity by the active ingredients.

As seen in Table 1, the results clearly indicate that all treatments wherein abamectin is applied in combination with thiamethoxam and thiabendazole do not affect the cold test results when compared to the untreated control. Results also showed that even the highest concentration of abamectin that was used in this study did not cause toxicity in watermelon plants. In a study conducted by Almeida et al. (2012), the authors' report that high concentrations of thiamethoxam used for seed treatment causes an increase in the percentage of normal seedlings after the cold test. Woodstock (1976) described the cold test as an examination that was originally developed to evaluate the effect of chemical treatments, especially fungicides, on seeds. Since then the test has evolved to become a vigor test capable of assessing the combined effects of genetic potential, specific treatment, and physiological condition of the seeds. Thus, even when germination values remain unchanged, seed treatment is always recommended as a method to overcome stressful environmental conditions such as those simulated by the cold test and accelerated aging test especially as the former enhances the physiological properties of seeds.

Analysis of seedling vigor, as measured through ESI (Table 1), revealed that treatment modalities $\mathrm{ST}_{4}$ and $\mathrm{ST}_{5}(0.300$ and $0.600 \mathrm{~g}$ of abamectin $+\mathrm{F}+\mathrm{I}$, respectively) lead to an increase in ESI as compared to the other treatments tested. Castro et al. (2008) also observed a similar increase in the vigor of the treated soybean seeds. In contrast, Bittencourt et al. (2000) found no effect of the insecticides thiodicarb and imidacloprid + thiodicarb on the emergence of corn seedlings. Dan et al. (2010) evaluated the effect of fipronil and thiamethoxam treatment on soybean seeds and found that there are no differences between the treated seeds and the check treatment which is indicative of the fact that the rate of speed of emergence was unrelated to seed treatment. The same authors also pointed out that the emergence rate was the main factor influencing rapid seedling establishment under field conditions. Seedlings with higher ESI perform better and possess greater stamina for withstanding stresses that could interfere with their normal growth and development (Dan et al., 2010).

\section{Influence of chemical treatment on the shoot length, shoot fresh, and root weight of watermelon plants infected with Meloidogyne javanica}

Infection of seeds with 5,000 eggs of Meloidogyne javanica had no significant impact on the SL and SFW of watermelon plants (Fig 1, 2).These results clearly demonstrate that the root-knot nematodes do not cause damage to the shoot growth of watermelon plants possibly because the shoot is less susceptible to infection by $M$. javanica. In a previously published study, Karsen and Moens (2006) have demonstrated that host plants display varying degrees of susceptibility to the parasite and that some plants are highly susceptible while others are less susceptible or resistant to RKN. The plants that are highly susceptible to the infestation permit the juveniles to enter the roots, reach maturity, and produce a large number of eggs. The resistant plants on the other hand suppress their development and thus do not allow reproduction.

In cases where there is a severe infection along with an absence of appropriate control measures, the yield loss can be extremely high to the extent that plants have been documented to die before reaching maturity.

It is well established that almost all the treated plants exhibit growth parameters that are superior to that of the untreated control (Figure 1). In this study however the treatments represented in Figs. 1 and 2 fail to show significant results for infestation of the watermelon crop by $M$. javanica. This result can be attributed to the level (5,000 eggs) of parasites inoculated in the watermelon seedlings. Singh and Khurma (2007) have reported that a direct relationship can be observed between gall numbers and inoculation level for all cultivars of tomato except for Mini Roma, which exhibited comparatively reduced variation in galls' number and plant 
Table 1. Standard Germination test (SGT\%), cold test (CT\%) and seedling emergence index (SEI) of watermelon seeds treated with abamectin, thiabendazole, and thiamethoxam.

\begin{tabular}{lccc}
\hline $\begin{array}{l}\text { Seed treatment } \\
\text { (abamectin (g) per 1000 seeds) }\end{array}$ & SGT & CT & SEI \\
\hline ST 1-0.000 & $84 \mathrm{a}$ & $76 \mathrm{a}$ & $2.77 \mathrm{~b}$ \\
ST 2* $-0.075+$ F + I & $83 \mathrm{a}$ & $78 \mathrm{a}$ & $3.00 \mathrm{ab}$ \\
ST 3*-0.150+ F + I & $78 \mathrm{ab}$ & $77 \mathrm{a}$ & $3.11 \mathrm{ab}$ \\
ST 4*-0.300+ F + I & $77 \mathrm{ab}$ & $76 \mathrm{a}$ & $3.25 \mathrm{a}$ \\
ST 5*-0.600+F+I & $78 \mathrm{ab}$ & $77 \mathrm{a}$ & $3.33 \mathrm{a}$ \\
\hline Average & 80 & 77 & 3.09 \\
\hline CV $(\%)$ & 3.01 & 3.29 & 10.12 \\
\hline
\end{tabular}

* $\mathrm{ST}_{2}$ to $\mathrm{ST}_{5}$ received $0.088 \mathrm{~g}$ of thiabendazole $(\mathrm{F})+0.192 \mathrm{~g}$ of thiamethoxam (I) per thousand seeds, respectively. Means followed by the same lowercase letters in a column do not differ by Tukey's test at $5 \%$ likelihood.

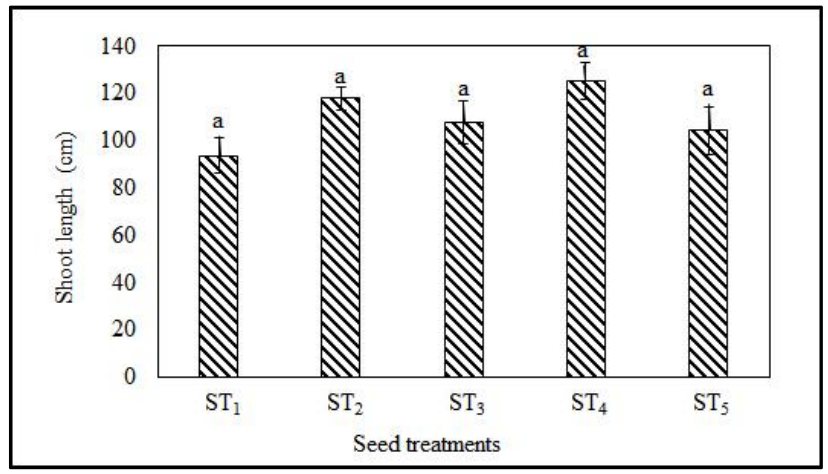

Fig 1. The effect of seed treatment on the seedling shoot length of watermelon plants infested with M. javanica. $* \mathrm{ST}_{2}$ to $\mathrm{ST}_{5}$ received $0.088 \mathrm{~g}$ of thiabendazole $(\mathrm{F})+0.192 \mathrm{~g}$ of thiamethoxam (I) per thousand seeds, respectively. Means followed by the same lowercase letters between horizontal bars and do not differ by Tukey's test at $5 \%$ likelihood.

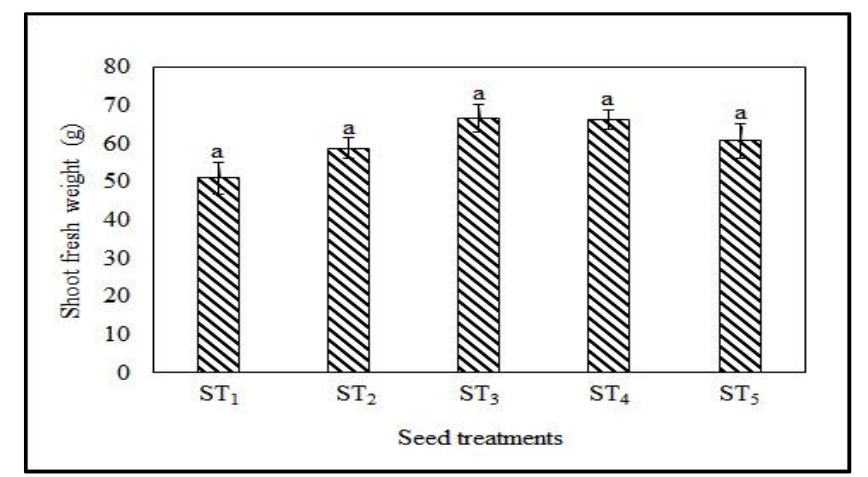

Fig 2. The effect of seed treatment on the shoot fresh weight of watermelon plants infested with M. javanica. $* \mathrm{ST}_{2}$ to $\mathrm{ST}_{5}$ received $0.088 \mathrm{~g}$ of thiabendazole $(\mathrm{F})+0.192 \mathrm{~g}$ of thiamethoxam (I) per thousand seeds, respectively. Means followed by the same lowercase letters between the horizontal bars and do not differ by Tukey's test at $\mathrm{p}<0.05$.

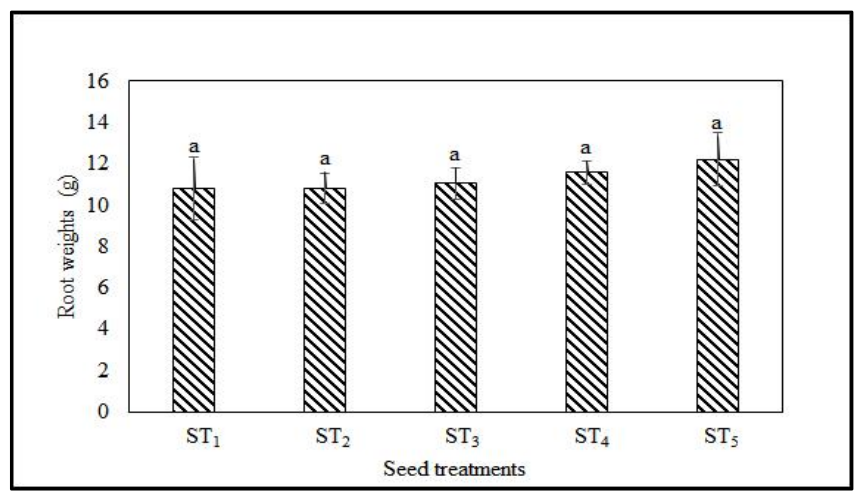

Fig 3. The effect of seed treatment on the root weights of watermelon plants infested with M. javanica. $* \mathrm{ST}_{2}$ to $\mathrm{ST}_{5}$ received $0.088 \mathrm{~g}$ of thiabendazole $(\mathrm{F})+0.192 \mathrm{~g}$ of thiamethoxam (I) per thousand seeds, respectively. Means followed by the same lowercase letters between horizontal bars and do not differ by Tukey's test at $5 \%$ likelihood. 


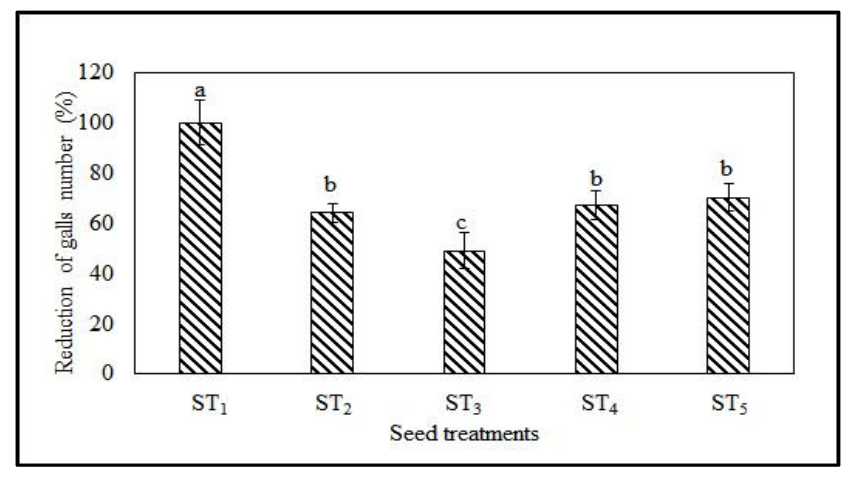

Fig 4. The effect of seed treatment in reducing the number of galls developed in roots of watermelon inoculated with 5,000 eggs of M. javanica. $* \mathrm{ST}_{2}$ to $\mathrm{ST}_{5}$ received $0.088 \mathrm{~g}$ of thiabendazole $(\mathrm{F})+0.192 \mathrm{~g}$ of thiamethoxam (I) per thousand seeds, respectively. Means followed by the same lowercase letters between the horizontal bars do not differ by Tukey's test at $5 \%$ likelihood.

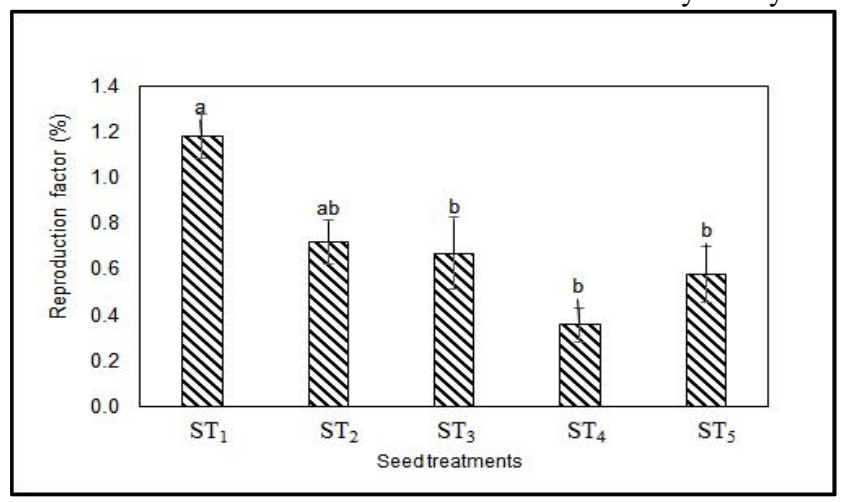

Fig 5. The effect of seed treatment in reducing the egg numbers developed in the roots of watermelon inoculated with 5,000 eggs of $M$ javanica. $* \mathrm{ST}_{2}$ to $\mathrm{ST}_{5}$ received $0.088 \mathrm{~g}$ of thiabendazole $(\mathrm{F})+0.192 \mathrm{~g}$ of thiamethoxam (I) per thousand seeds, respectively. Means followed by the same lowercase letters between horizontal bars and do not differ by Tukey's test at $5 \%$ likelihood.

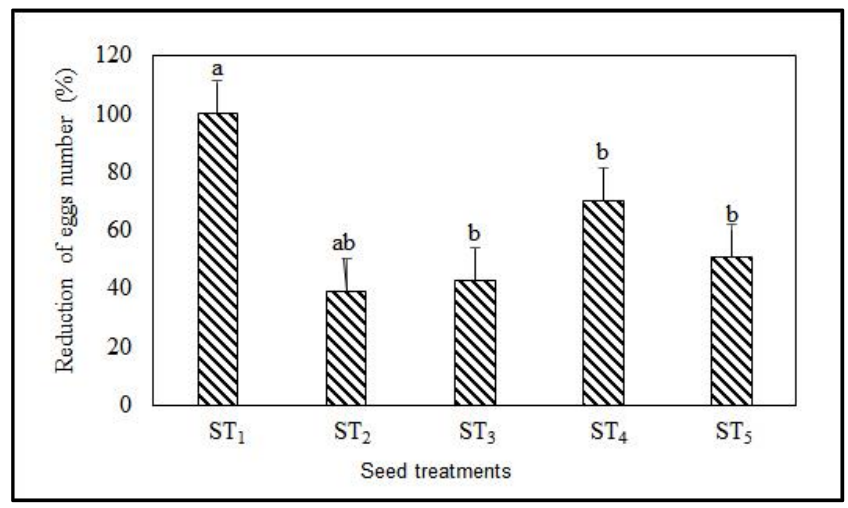

Fig 6. Reproduction factor of watermelon plants inoculated with 5,000 eggs of $M$. javanica. $* \mathrm{ST}_{2}$ to $\mathrm{ST}_{5}$ received $0.088 \mathrm{~g}$ of thiabendazole $(\mathrm{F})+0.192 \mathrm{~g}$ of thiamethoxam (I) per thousand seeds, respectively. Means followed by the same lowercase letters between horizontal bars do not differ by Tukey's test at $5 \%$ likelihood.

weight with increasing inoculum levels. The abovementioned study also noted that as compared to the control, the plant weight for all cultivars, except Mini Roma, decreased with increasing inoculum levels. When RW values of all watermelon plants inoculated with $M$. javanica were compared to that of the untreated control it was observed that the $M$. javanica inoculated plants did not show a significant reduction for their root systems (Fig 3). It can be attributed to the use of varieties that are less susceptible to the parasite. López-Pérez et al. (2006) reported that identification and use of varieties that are resistant and/ or tolerant to root-knot nematodes has the potential to be a viable option for minimizing the loss caused by root-knot nematodes. The quality and quantity of fruit production is another factor that needs to be taken into consideration before further investigations are conducted. This is because it has been observed often that there is variability in the fruit borne by the resistant, less susceptible, and highly susceptible varieties, with the resistant varieties not producing fruit of desirable taste and quality. According to Singh and Khurma (2007), susceptibility of the different tomato varieties has important implications on both yield as well as economic returns. Hence, accurate information regarding susceptibility to RKN in other vegetable crops can be useful to farmers for the process of selecting the appropriate variety for cultivation on RKN infested fields. 

Effect of chemical treatment on reduction of root-knot
nematodes in watermelon plants

The GN and EN of $M$. javanica were seen to reduce when different concentrations of abamectin were inoculated into pots containing the watermelon seedlings (Fig 4, 5). When $0.075 \mathrm{~g}\left(\mathrm{ST}_{1}\right), 0.150 \mathrm{~g}\left(\mathrm{ST}_{2}\right), 0.300 \mathrm{~g}\left(\mathrm{ST}_{3}\right)$ and $0.600 \mathrm{~g}\left(\mathrm{ST}_{4}\right)$ of abamectin were used for seed treatment in combination with $0.088 \mathrm{~g}$ of thiabendazole and $0.192 \mathrm{~g}$ of thiamethoxam, a reduction of $64 \%, 49 \%, 33 \%$ and $30 \%$, respectively, was seen for the number of galls per $10 \mathrm{~g}$ roots (Figure 4). Korayem et al. (2008) reported that application of abamectin at the tested concentrations significantly reduced most nematode parameters while simultaneously enhancing plant growth parameters. A study by Khalil (2013) stated that efficacy of abamectin for seed treatment, soil drench application, and root dipping has been evaluated against several genus of parasitic nematodes such as Meloidogyne incognita, $M$. arenaria, $M$. javanica, Tylenchulus semipenetrans and Rotylenchulus reniformis.

In a study conducted by Faske and Starr (2007), the authors noted that abamectin is capable of protecting roots from RKN-mediated galling only for $5 \mathrm{~cm}$ along the growing root and further beyond, abamectin cannot protect the growing root. Contrary to this, results of this study show that application of abamectin has a distinct positive influence against infestation by $M$. javanica. In addition, infestation by root-knot nematode was not seen to affect the seedling length, fresh shoot weight or dry root weight of watermelon plants. Interestingly, Lopez-Pérez et al. (2011) have reported that the action of abamectin is inconsistent in controlling root-knot nematodes. They attributed this phenomenon to the strong adsorption of abamectin by soil particles, which results in immobilization of abamectin in the soil.

Data shown in Fig. 5 revealed that results expressed in terms of percentages were smaller for test samples as compared to the untreated control. The various treatments $\left(\mathrm{ST}_{2}, \mathrm{ST}_{3}, \mathrm{ST}_{4}\right.$ and $\left.\mathrm{ST}_{5}\right)$ used for managing infestation of nematode eggs in watermelon roots generated a reduction of $39 \%, 43 \%, 70 \%$ and $51 \%$, respectively. In general, it was observed that all treatments used in this study effected a reduction in the EN of watermelon roots as compared to the untreated control $\left(\mathrm{ST}_{1}\right)$. Monfort et al. (2006) have documented a number of cases wherein abamectin seed treatment has been successful for the control of RKN in a number of crops.

The RF of M. javanica in watermelon plants was seen to reduce upon treatment with various concentrations of abamectin (Fig 6). For the watermelon plants that were not subjected to treatment, the values of $R F(F>1=1.2)$ obtained indicated towards the possibility of lower susceptibility (Fig $6)$. However, the RF values determined for watermelon plants treated with different concentration of abamectin in combination with thiabendazole and thiamethoxam was lower as compared to the control untreated. The results outlined above lead us to hypothesize that there is a degree of tolerance present in the cultivated crops with respect to nematode infestation. This can be attributed to both management of treatment techniques as well as an inherent low aggressiveness of $M$. javanica towards untreated watermelon plants. As per results published by Vovlas et al. (2005), the RKN of specie $M$. javanica is less aggressive towards potato as compared to M. chitwoodi and M. hapla. Regardless, an infestation is still capable of severely impairing potato growth. The same authors also suggested that correct diagnosis and estimation of soil population levels of $M$. javanica, as well as those of other RKN, should be conducted prior to planting so as to facilitate effective integrated management of these nematodes on potato crops.

\section{Materials and Methods}

\section{Plant materials}

The study was conducted at the Laboratory of Seeds Analysis as well as the greenhouse of the Universidade Federal de Pelotas. The watermelon seed lots, cultivar Crimson Sweet, were treated with five abamectin concentrations: $0.075 \mathrm{~g}$ $\left(\mathrm{ST}_{2}\right) ; 0.150 \mathrm{~g}\left(\mathrm{ST}_{3}\right) ; 0.300 \mathrm{~g}\left(\mathrm{ST}_{4}\right)$ and $0.600 \mathrm{~g}\left(\mathrm{ST}_{5}\right)$. The treatments were in combination with single doses of thiabendazole $(0.080 \mathrm{~g})$ and thiamethoxam $(0.019 \mathrm{~g})$. Untreated controls were also included in the study.

The mixed solution ( $4.9 \mathrm{~mL} 1000 \mathrm{seed}^{-1}$ volume) was used for the purpose of treatment. For treating the seeds, plastic bags of 31 capacity were employed. Untreated seeds were treated with pure water in the bags at a volume equivalent to that of the solution used for the other treatments using the same methodology. Subsequent to the treatment, all seeds were dried at room temperature for $24 \mathrm{~h}$.

The treated and untreated seeds were divided in two portions. The first portion was subjected to the germination test in accordance to the procedures described in the Rules for Seed Testing (Brasil, 2009). This was followed by the cold test and indexing of seedling emergence. The second portion of seeds was used for analyzing establishment of seedlings followed by nematode inoculation.

\section{Nematode inoculation}

Establishment of seedlings: The treated and untreated seeds were planted in trays using a mixture of $40 \%$ Plantmax ${ }^{\circledR}$ substrate and $60 \%$ sieved soil that had been sterilized by autoclaving over three days for $1 \mathrm{~h}$ at $120^{\circ} \mathrm{C}$. Twenty days post-sowing, seedlings of the Crimson Sweet, Citrullus lanatus, were transplanted into pots of $1.8 \mathrm{~L}$ capacity. To these seedlings a $10 \mathrm{~mL}$ suspension containing 5,000 eggs and second-stage juveniles (J2) of M. javanica were applied. Nematode inocula: Meloidogyne javanica was cultured alternately on tomato (Lycopersicon esculentum). The parasite population was extracted from tomato roots kept in greenhouse conditions. Infected tomato roots were rinsed and immersed in $\mathrm{H}_{2} \mathrm{O}$ in order to remove soil and other debris. The infected roots were cut into $2-3 \mathrm{~cm}$ pieces and blended in a solution containing $0.5 \% \mathrm{NaOCl} /$ liter $\mathrm{H}_{2} \mathrm{O}$ for $15 \mathrm{~s}$. The amount of solution used for the blending purpose was enough just to cover the roots. The suspension that was thus obtained was poured through 20 mesh sieves and washed with running water so as to retain soil and other debris. The resultant suspension that now was composed of eggs and $\mathrm{J} 2$ was then poured through 500 mesh sieves and washed under a slow stream of cold tap water in order to remove $\mathrm{NaOCl}$. Eggs and second-stage juveniles (J2) were collected from the 500 mesh sieve and transferred to a $100 \mathrm{~mL}$ beaker. The suspension and residues were shifted to a centrifuge tube. All centrifuge tubes were kept balanced with the identical counterbalance. In the same suspension, $1 \mathrm{~cm}$ of kaolin was added and then mixed with a glass rod. All samples were then centrifuged for $5 \mathrm{~min}$ at $1750 \mathrm{rpm}$. Subsequently, tubes were removed from the centrifuge and the supernatant was discarded. A sucrose solution $\left(400 \mathrm{~g} / 750 \mathrm{~mL} \mathrm{H}_{2} \mathrm{O}\right)$ was added to dilute the pellet. The resuspended pellet was then placed into tubes and centrifuged at $1750 \mathrm{rpm}$ for $1 \mathrm{~min}$ again. The tubes were removed from the centrifuge and the supernatant was passed 
through sloped 500 mesh and washed with running water so as to eliminate the excess sucrose. Finally, the suspension thus obtained was collected in a $100 \mathrm{~mL}$ beaker. The suspension $(20 \mathrm{~mL})$ was used for quantifying eggs and J2. To this purpose, $1 \mathrm{~mL}$ of the suspension was added to a Peter's chamber. This was repeated three times and the average was calculated. One milliliter of the suspension was diluted using $9 \mathrm{~mL}$ of water; this dilution was then used to estimate the total volume of liquid that contained 5,000 eggs. The final volume of the eggs and $\mathbf{J} 2$ suspension was adjusted such that the total volume applied per plant was uniform $10 \mathrm{~mL}$. Egg masses and $\mathrm{J} 2$ were counted on at least 60 plants. The nematode reproduction in watermelon plants was assessed six weeks after inoculation with $M$. javanica.

\section{Physiological quality evaluation}

Standard germination (SG): Four subsamples of 50 seeds were used for this assay and the test was performed using paper towels. Evaluations were conducted five and fourteen days after sowing and the results are expressed in terms of percentage of normal seedlings as has been described previously by Ista (2012).

Cold test (CT): Four subsamples of 50 seeds were used for this assay and the test was performed on paper towels. Evaluations were conducted seven days after sowing and the results were expressed in terms of percentage of normal seedlings as has been described previously by Ista (2012).

Emergence speed index (ESI): The emergence speed index was calculated on the basis of four replicates of 50 seeds. The number of germinated normal seedlings was counted on a daily basis till a constant number of seedlings was obtained. For each replicate, the emergence speed index was calculated by summing the number of seedlings germinated on each day and dividing by the number of days elapsed since sowing the seeds in trays. The emergence index for each treatment was calculated based on the procedure previously described by Maguire (1962).

\section{Nematode evaluations}

Shoot length (SL): Watermelon plants were collected 55 days after inoculation with $M$. javanica. The shoot length of each plant was measured and the results are expressed in centimeters $(\mathrm{cm})$.

Shoot fresh weight (SFW): For each plant, the fresh weight of shoot materials (stems and leaves) was determined using a digital balance. The results are expressed in grams (g).

Root weight (RW): For each plant, the root materials were placed in individual brown paper bags and marked. The weight of these bags was recorded using a digital balance and the results are expressed in grams $(\mathrm{g})$.

Gall numbers (GN): For each plant, $10 \mathrm{~g}$ of watermelon roots were used to count the galls of the root system. The average obtained from six replicates was used for further analysis.

Eggs number (EN): A $0.5 \%$ sodium hypochlorite solution was used to grind the roots in a blender. The eggs, and any newly hatched juveniles in suspension, were counted using a Peter's chamber and a light microscope. The eggs and J2 suspension were agitated and $1 \mathrm{~mL}$ of the suspension was transferred to the counting slide. This was repeated three times and the average was calculated. The results are expressed in terms of percentage of eggs.

Reproduction factor (RF): The final population number (FP) and initial population (IP) figures were used for obtaining the reproduction factor (FP/IP). IP corresponds to number of eggs used in the nematode inoculation while the number of eggs and newly hatched juveniles in the final suspension are considered as the FP value. As RF = FP/IP, a value equal to or higher than 1.0 was taken as indicative of susceptibility (S), while a value lower than 1.0 was taken as indicative of resistance $(\mathrm{R})$.

\section{Statistical analysis}

The experimental design used for this study was randomized complete blocks design with four blocks and six replications. To assess seed quality four replicates of the experiment were used and the design utilized to this purpose was completely randomized. The analysis of variance was computed by Tukey's test $(\mathrm{p}<0.05)$ using the statistical program Assistat ${ }^{\circledR}$. Six replicates of every inoculum level was employed for each inoculation of Meloidogyne javanica in watermelon seedlings. A control without any inoculation was also used.

\section{Conclusion}

The watermelon seed quality was not affected by the concentration of abamectin when used in combination with thiabendazole and thiamethoxam. Abamectin, in concentrations of $0.75 \mathrm{~g}$ up to $600 \mathrm{~g} /$ ia of abamectin per 1000 seeds, when applied together with thiabendazole and thiamethoxam is an effective control agent for reducing the number of eggs and second-stage juveniles (J2) in 'Crimson Sweet' watermelon plants.

\section{Acknowledgments}

This research was supported by a grant from the Coordination for the Improvement of Higher Education Personnel (CAPES) at Universidade Federal de Pelotas.

\section{References}

Almeida AS, Tillmann MAA, Villela FA, Pinho MS (2009) Bioativador no desempenho fisiológico de sementes de cenoura. Rev Bras Sementes. 31:87-95.

Almeida AS, Villela FA, Meneghello GE, Lauxen LR, Deuner C (2012) Desempenho fisiológico de sementes de aveia-preta tratadas com tiametoxan. Semina. 33:16191628.

Bittencourt SEM, Fernandes MA, Ribeiro MCR, Vieira RD (2000) Desempenho de sementes de milho tratadas com inseticidas sistêmicos. Rev Bras Sementes. 22: 86-93.

Brasil (2009) Regras para análise de sementes. Ministério da agricultura: Brasília

Castagnone-Sereno P (2002) Genetic variability in parthenogenetic root-knot nematodes, Meloidogyne spp., and their ability to overcome plant resistance genes. J Nematol. 4: 605-608.

Castro PRC, Pereira MA (2008) Bioativadores na agricultura. In: Gazzoni DL (ed) Tiametoxam: uma revolução na agricultura brasileira. Petrópolis Vozes.

Dan LGM, Dan HA, Barroso ALL, Bracinni AL (2010) Qualidade fisiológica de sementes de soja tratadas sob efeito do armazenamento. Rev Bras Sementes. 32:131-139.

Dan LGM, Dan HA, Bracinni AL, Albrecht LP, Ricci TT, Piccinin GG (2011) Desempenho de sementes de soja tratadas com inseticidas e submetidas a diferentes períodos de armazenamento. RevBras Cienc Agr. 6:215-222. 
Dan LGM, Dan HA, Piccinin GG, Ricci TT, Ortiz AHT (2012) Tratamento de sementes com inseticida e a qualidade fisiológica de sementes de soja. Rev Caatinga. 25:45-51.

Dorman M, Nelson S. (2012). Root-knot nematodes on cucurbits in Hawai'i. Plant Disease. 84:1-5.

Faske TR, Starr JL (2007) Cotton root protection from plantparasitic nematodes by abamectin treated seed. J Nematol. 39:27-30.

Fischer IH, Silva AL, Amorim L (2008) Doenças póscolheita em citros e caracterização da população fúngica ambiental no mercado atacadista de São Paulo. Plant Pathol. 33:219-226.

Gassen D (2006) Tratamento de sementes: importante estratégia de proteção nas fases de germinação e de plântula. Rev Plant Direto. 93:26-29.

Ista (International Seed Testing) (2012) International rules for seed testing. Int Seed Test Assoc, Bassersdorf, Switzerland.

Khalil MS (2013) Abamectin and azadirachtin as ecofriendly promising biorational tools in integrated nematodes management programs. J Plant Pathol Microbiol. 4:2-7.

Karsen G, Moens M (2006) Root-knot nematodes. In: Perry RN, Moens M (eds) Plant Nematology CABI.

Korayem AM, Mahmoud MAY, Moawad MMM (2008) Effect of chitin and abamectin on Meloidogyne incognita infesting rapeseed. J Plant Protection Res. 48:365-370.

López-Pérez JL, Strange M, Kaloshian I, Ploeg A (2006) Differential response of $\mathrm{Mi}$ gene-resistant tomato rootstocks to root-knot nematodes (Meloidogyne incognita). Crop Prot. 25: 382-388.

López-Pérez JA, Edwards S, PLOEG A (2011) Control of root-knot nematodes in tomato in stone woll substrate with biological nematicides. J Nematol. 43:110-117

Ludwig MP, Lucca-Fillho, AO Baudet L, Dutra LM, Gonçalves AS, Crizel RL (2011) Qualidade de sementes de soja armazenadas após recobrimento com aminoácidos, polímero, fungicida e inseticida. Rev Bras Sementes. 33:395 - 406 .

Maguire JD (ed) (1962). Speed of germination-aid in selection and evaluation for seedling emergence and vigor. Crop Sci. 2:176-177.
Monfort WS, Kirkpatrick TL, Long DL, Rideot T (2006) Efficacy of a novel nematicidal seed treatment against Meloidogyne incognita on cotton. J Nematol. 38:245-249.

Moraes MHD, Menten JOM, Gravena JC, Alves CA (2003) Controle químico de fusarium moniliforme em sementes de milho: metodologia de avaliação e efeitos sobre a qualidade fisiológica. Fitopatol Bras. 28:626-632.

Nerbass FR, Casa RT, Angelo HR (2008) Sanidade de sementes de milho comercializadas na safra agrícola de 2006/07 em Santa Catarina e no Rio Grande do Sul. Rev Cienc Agrovet. 7:30-36.

Oliveira JJV, Toledo MCF, Benato EA, Sigrist JMM, Yotsuyanagi K (2002) Tratamento pós-colheita de laranja pêra com imazalil e tiabendazol: eficiência e níveis residuais dos fungicidas. Rev Bras de Toxicol. 15:25-32.

Singh SK, Khurma UR (2007) Susceptibility of six tomato cultivars to the root-knot nematode, Meloidogyne incognita. J Na Sci. 13:73-77.

Vitti AJ, Neto URR, Araujo, FG, Santos LC, Barbosa KAG, Rocha MR (2014) Effect of soybean seed treatment with abamectin and thiabendazole on heterodera glycines. Nematropic. 44:74-80.

Vovlas N, Mifsud D, Landa BB, Castillo P (2005) Pathogenicity of the root-knot nematode Meloidogyne javanica on potato. Plant Pathol. 54:657-664.

Woodstock LW (1976) Progress reports on seed vigor testing handbook. Newsletter of association of official seed testing analysts (AOSA). USA, Mississippi, 1976, 50:1-78. 